\title{
PENERAPAN PSAK 71 DAN DAMPAKNYA TERHADAP KEWAJIBAN PENYEDIAAN MODAL MINIMUM BANK
}

\author{
Suroso \\ Sekolah Tinggi Ilmu Ekonomi Wiyatamandala \\ surosocuk@gmail.com
}

\begin{abstract}
PSAK 71 is about Financial Instrument has been applied since January $1^{\text {st }} 2019$. But in fact the implementation of this PSAK is still in consideration. DSAK-IAI much more concern about the accuracy of the implementation of PSAK 71 especially in Financial and Banking Sector. Finally DSAK IAI decided that later in 2020 all firms should implement this regulation. Some firms are allow to implement PSAK 71 early in order to make sure the firms can learn and sincronize their report with this PSAK. This research conducted base on current situation of the Bank where researcher work. This research is qualitative study of the impact of this new PSAK 71 to the Bank where Researcher work. Finding of this research, the implementation of PSAK 71 has positive impact, it could give relevant information for the user of financial report to give valuation about total, period and uncertainty about future cash flow. But there is some negative impact such as it will increase CKPN and decrease KPPM (or Capital Adequacy Ratio). There will be about 55,68\% increasing of CKPN and $0,28 \%$ decreasing of KPPM. It is very important for Bank to make good preparation from the strategic aspect, technical and operational aspect because the decreasing of CKPN could impact the Bank performance and there will be more risk to be handled for the Bank.
\end{abstract}

Keyword : PSAK-71, Financial Instument, Capital Adequacy Ratio, KPPM, CKPN, Bank, Banking Risk

\section{PENDAHULUAN}

Sebagai perwujudan komitmen konvergensi International Financial Reporting Standards (IFRS), Dewan Standar Akuntansi Keuangan Ikatan Akuntan Indonesia (DSAK IAI) telah mengesahkan Pernyataan Standar Akuntansi Keuangan 71 (PSAK 71) tentang Instrumen Keuangan yang merupakan konvergensi dari IFRS 9 Financial Instrumens yang dikeluarkan oleh International Accounting Standard Board (IASB). PSAK 71 tentang Instrumen Keuangan ini sedianya akan berlaku secara efektif pada tanggal 1 Januari 2019. Namun, berdasarkan beberapa pertimbangan, diantaranya kesiapan dan komitmen dari industri terdampak, khususnya industri perbankan, terkait implementasi PSAK 71 nantinya dapat berjalan dengan baik dan tepat waktu, pada akhirnya DSAK IAI memutuskan untuk memberikan kelonggaran tanggal efektif PSAK 71 selama 1 (satu) tahun menjadi 1 Januari 2020 dan PSAK 71 ini tetap memperkenankan entitas yang ingin menerapkan PSAK 71 ini lebih awal. 
Secara umum, PSAK 71 mengatur beberapa perubahan persyaratan terkait instrumen keuangan, yaitu:

\section{- Klasifikasi dan Pengukuran}

Salah satu perubahan mendasar pada klasifikasi aset keuangan dalam PSAK 71 ini adalah pergeseran berdasarkan business model. Klasifikasi dan pengukuran instrumen keuangan nantinya tidak lagi berdasarkan intensi manajemen, namun pengaturan klasifikasi dan pengukuran instrumen keuangan selanjutnya berdasarkan karakteristik kontraktual arus kas dan bisnis model dari entitas.

Untuk selanjutnya, klasifikasi dan pengukuran terdiri dari fair value through profit or loss (FVTPL), fair value through other comprehensive income (FVOCI) dan amortized cost.

\section{- Penurunan Nilai}

Perubahan mendasar dari PSAK 71 ini adalah peningkatan kualitas pelaporan keuangan terkait pengakuan penurunan nilai instrumen keuangan yang diharapkan informasi yang dihasilkan lebih tepat waktu, relevan dan dapat dipahami oleh pengguna laporan keuangan.

Jika pada PSAK 55 konsep penurunan nilai yang dipakai adalah incurred loss model yaitu penurunan nilai pada instrumen keuangan dilakukan jika dan hanya terdapat bukti obyektif penurunan nilai, namun alam PSAK 71 konsep yang digunakan adalah expected loss model yaitu penurunan nilai pada instrumen keuangan dilakukan berdasarkan kerugian kredit yang diharapkan (expected credit loss). Oleh karena itu, dalam PSAK 71 ini, setiap tanggal pelaporan entitas perlu menilai apakah risiko kredit atas instrumen keuangan telah meningkat secara signifikan sejak pengakuan awal dengan menggunakan informasi forward-looking yang wajar dan terdukung (reasonable and supportable information).

\section{- Akuntansi Lindung Nilai}

Perubahan signifikan dalam PSAK 71 ini dibandingkan dengan PSAK 55 adalah terkait dengan persyaratan akuntansi lindung nilai, dimana laporan keuangan nantinya akan mencerminkan manajemen risiko entitas. Jika dalam PSAK 55, lindung nilai dapat dianggap efektif jika memenuhi persyaratan tes efektivitas 80-125\%, namun di PSAK 71 persyaratan tes efektivitas tersebut tidak diperlukan lagi dan selanjutnya didasarkan persyaratan yang lebih umum berdasarkan pertimbangan manajemen. 
Mempertimbangkan adanya beberapa perubahan yang cukup mendasar sebagaimana tersebut diatas, khususnya terkait dengan penurunan nilai (impairment), maka dapat diidentifikasi bahwa penerapan PSAK 71 akan memberikan dampak yang cukup signifikan, khususnya terhadap industri perbankan, diantaranya adalah pemenuhan Kewajiban Penyediaan Modal Minimum (KPMM/Capital Adequacy Ratio). Seberapa besar dampak penerapan PSAK 71 ini terhadap pembentukan Cadangan Kerugian Penurunan Nilai (CKPN), hal tersebut akan dibahas lebih lanjut sejalan dengan telah dilakukannya simulasi terkait hal tersebut pada salah satu Bank Swasta Nasional yang masuk kategori Bank BUKU 1 (Bank Umum Kegiatan Usaha).

\section{PEMBAHASAN}

\section{PENURUNAN NILAI (IMPAIRMENT)}

Sebelum dilakukan pembahasan terhadap impairment, perlu dipahami juga bahwa penerapan PSAK 71 ini menganut "principle based" dan jauh berbeda dengan PSAK 50/55 yang menganut prinsip "rule based". Sesuai dengan "principle based", maka dalam PSAK 71 ini hanya mengatur hal-hal yang prinsip, sangat berbeda dengan "rule based" yang mengatur secara lebih detail terkait penyajian laporan keuangan.
Sebagaimana telah diuraikan sebelumnya bahwa pada PSAK 71 penurunan nilai tidak dilakukan menggunakan incurred credit loss seperti PSAK 55, tetapi menggunakan expected credit loss. Pendekatan yang digunakan dalam pengakuan expected credit loss, terdiri dari:

- Lifetime Expected Credit Losses

Expected credit losses yang dihasilkan dari semua kemungkinan peristiwa gagal bayar selama jangka waktu yang diharapkan atas instrumen keuangan.

- 12-Month Expected Credit Losses Expected credit losses yang dihasilkan dari peristiwa gagal bayar pada instrumen keuangan yang memungkinan terjadi selama 12 bulan setelah tanggal laporan.

Untuk menentukan apakah cadangan kerugian (loss allowance) diukur menggunakan Lifetime Expected Credit Losses atau 12-Month Expected Credit Losses, sangat tergantung sejauh mana terjadi perubahan secara signifikan dalam risiko kredit instrumen keuangan sejak pengakuan awal. Dalam hal menentukan apakah risiko kredit instrumen keuangan telah mengalami kenaikan secara signifikan sejak pengakuan awal, maka perlu dilakukan perbandingan antara risiko gagal bayar instrumen keuangan pada tanggal pengakuan awal dengan tanggal 
pelaporan dengan mempertimbangkan informasi terkait yang tersedia (reasonable and supportable information). Bank tidak harus melakukan penelitian yang mendalam untuk mendapatkan informasi yang diperlukan dalam menentukan apakah risiko kredit telah meningkat secara signifikan sejak pengakuan awal. Informasi kualitatif baik intern atau ekstern, juga dapat digunakan untuk menentukan apakah isntrumen keuangan telah mengalami peningkata risiko kredit secara signifikan. Beberapa informasi kualitatif tersebut antara lain; perubahan signifikan internal credit rating terhadap instrumen keuangan, perubahan macro ekonomi yang berpengaruh negatif terhadap debitur, perubahan yang memburuk terhadap indicator pasar, tunggakan pokok dan/atau bunga, perubahan membruk dari debitur, dll.

Salah satu hal penting dalam penerapan PSAK 71 ini adalah adanya 3 "bucket" berbeda dengan PSAK 55 yang mengenal beberapa bucket. Ke-3 bucket tersebut, meliputi:

\section{- Bucket 1}

- Kualitas kredit baik

- Tidak ada penurunan yang signifikan sejak pengakuan awal.

- Semua instrumen hutang yang diukur dengan biaya perolehan diamortisasi (amortized cost) atau pada nilai wajar melalui pendapatan komprehensif lainnya (FVTOCI), pada awalnya diklasifikasikan dalam bucket 1 tanpa memperhatikan kualitas kredit

\section{- Bucket 2}

- Kualitas kredit kurang baik

- Terjadi penurunan kualitas kredit yang signifikan sejak pengakuan awal atau arus kas kemungkinan tidak mencukupi.

\section{- Bucket 3}

- Kualitas kredit memburuk

- Terjadi penurunan kualitas kredit yang signifikan sejak pengakuan awal atau arus kas kemungkinan tidak mencukupi.

Dalam penentuan cadangan kerugian, Bucket 1 harus dilakukan melalui 12Month Expected Credit Losses, sementara untuk Bucket 2 dan 3 harus dilakukan melalui Lifetime Expected Credit Losses. Dalam menentukan penilaian apakah instrumen keuangan mengalami peningkatan risiko kredit yang signifikan dan mengukur cadangan kerugian, Bank dapat melakukannya secara individual, kolektif atau keduanya, tergantung karakteristik dan informasi risiko kredit yang tersedia. Pengukuran cadangan kerugian ini, sangat disarankan menggunakan pendekatan secara kolektif 
untuk memenuhi tujuan pengakuan lifetime expected credit losses ketika terjadi peningkatan risiko kredit. Dalam melakukan penilaian secara kolektif, Bank dapat mengelompokan instrumen keuangan berdasarkan risiko kredit yang mempunyai karakter relatif sama (shared credit risk), misalnya tipe instrumen, jenis kolateral, industry, lokasi geografis debitur, sisa jangka waktu, dll.

Dalam mengukur lifetime expected credit losses secara kolektif, maka Bank dapat menggunakan informasi kredit yang komprehensif, yang terdiri dari:

- Informasi masa lampau/data historis (past due information)

- Prediksi makro ekonomi masa depan (forward looking macroeconomic information)

Sesuai dengan konsep "principle based", PSAK 71 tidak memberikan batasan atau ketentuan terkait seberapa jauh informasi data historis dan prediksi macroeconomic masa depan yang diperlukan.

DAMPAK TERHADAP KEWAJIBAN PENYEDIAAN MODAL MINIMUM (KPMM)
Berdasarkan analisa/simulasi yang dilakukan terhadap salah satu bank swasta nasional yang masuk dalam Bank dengan Kategori Bank Umum Kegiatan Usaha (BUKU) “2”, secara umum dapat disampaikan bahwa penerapan PSAK 71 ini berdampak secara signifikan terhadap pencapaian laba/rugi yang pada akhirnya berpengaruh secara negatif terhadap aspek permodalan. Simulasi yang dilakukan terhadap laporan keuangan selama 4 triwulan, berdasarkan data laporan keuangan publikasi, dengan membandingkan antara penerapan PSAK 55 dengan menggunakan 5 bucket, dengan penerapan PSAK 71 yang menggunakan 3 bucket, dengan kondisi ceteris paribus. Hasil simulasi menunjukkan bahwa terdapat peningkatan yang signifikan terhadap pembentukan Cadangan Kerugian Penurunan Nilai (CKPN) sebesar 55,68\%. Hasil simulasi ini semakin mempertegas informasi yang telah dilakukan berkembang selama ini bahwa penerapan PSAK 71 ini memberikan dampak terhadap peningkatan CKPN sebesar $30 \%$ - 50\% dari CKPN existing. 
Tabel 1. Hasil Simulasi Cadangan Kerugian Penurunan Nilai (CKPN) PSAK 55 dan PSAK

\begin{tabular}{|l|r|r|r|r|r|}
\hline \multicolumn{1}{|c|}{ Keterangan } & TriwulanI & Triwulan II & Triwulan III & Triwulan IV & Rata-rata \\
\hline CKPNPSAK55 & 15,201 & 17,198 & 18,784 & 21,364 & 18,137 \\
\hline CKPNPSAK71 & 24,530 & 27,176 & 28,513 & 32,373 & 28,148 \\
\hline 96 Naik (Turun) & 61.3796 & 58.0296 & 517996 & 51.5396 & 55.6896 \\
\hline Sumber: data diolah &
\end{tabular}

Berkaitan dengan dampak penerapan PSAK 71 ini terhadap kecukupan Kewajiban Penyediaan Modal Minimum (KPMM/Capital Adequacy Ratio), simulasi dilakukan hanya terhadap perubahan modal inti, sementara untuk komponen modal pelengkap dan Aktiva Tertimbang Menurut Risiko (ATMR) relatif tidak berubah. Sebagaimana telah diketahui bahwa rasio KPMM/CAR merupakan perbandingan antara modal (modal inti dan modal pelengkap) dengan
ATMR. Penggunaan perubahan modal ini didasari pertimbangan bahwa peningkatan pembentukan CKPN sangat besar pengaruhnya terhadap pencapaian profitabilitas (laba/rugi) dan pada akhirnya juga sangat berpengaruh terhadap modal inti. Perlu dipahami pula bahwa dalam perhitungan KPMM/CAR di Bank, khususnya modal inti terdiri dari modal inti utama yang salah satu komponennya adalah laba tahun berjalan dan laba tahuntahun lalu, dan modal inti tambahan.

Tabel 2. Perbandingan Kecukupan Penyediaan Modal Minimum (KPPM) per Triwulan

PSAK 55 dan PSAK 71

\begin{tabular}{|l|r|r|r|r|r|}
\hline \multicolumn{1}{|c|}{ Keterangan } & Triwulan I & Triwulan II & Triwulan III & Triwulan IV & Rata-rata \\
\hline Modal Inti & $1,147,405$ & $1,180,363$ & $1,201,300$ & $1,226,734$ & $1,188,951$ \\
\hline Modal Pelengkap & 37,271 & 33,802 & 35,491 & 36,678 & 35,811 \\
\hline Total Modal & $1,184,676$ & $1,214,165$ & $1,236,791$ & $1,263,412$ & $1,224,761$ \\
\hline ATMR & $3,636,757$ & $3,513,569$ & $3,595,367$ & $3,757,362$ & $3,625,764$ \\
\hline KPMM (PSAK 55) & $32.58 \%$ & $34.56 \%$ & $34.40 \%$ & $33.62 \%$ & $33.79 \%$ \\
\hline Modal Inti & $1,138,076$ & $1,170,385$ & $1,191,571$ & $1,215,725$ & $1,178,939$ \\
\hline Modal Pelengkap & 37,271 & 33,802 & 35,491 & 36,678 & 35,811 \\
\hline Total Modal & $1,175,347$ & $1,204,187$ & $1,227,062$ & $1,252,403$ & $1,214,750$ \\
\hline ATMR & $3,636,757$ & $3,513,569$ & $3,595,367$ & $3,757,362$ & $3,625,764$ \\
\hline KPMM (PSAK 71) & $32.32 \%$ & $34.27 \%$ & $34.13 \%$ & $33.33 \%$ & $33.51 \%$ \\
\hline \% Naik (Turun) & $0.26 \%$ & $0.28 \%$ & $0.27 \%$ & $0.29 \%$ & $0.28 \%$ \\
\hline
\end{tabular}

Berdasarkan perubahan modal inti antara penerapan PSAK 55 dan PSAK 71 menunjukkan bahwa dengan penerapan PSAK 71 ini, KPMM/CAR Bank mengalami penurunan rata-rata $0,28 \%$, artinya jika menggunakan PSAK 71 maka KPMM/CAR akan turun sebesar $0,28 \%$ dibandingkan jika menggunakan PSAK 55. Jika dibandingkan peningkatan CKPN yang demikian besar (sebesar 55,68\%) 
dengan relatif kecilnya pengaruh terhadap KPMM/CAR, tentunya hal ini tidak dapat dimaknai secara "hitam putih", artinya kondisi ini tidak serta merta berlaku bagi Bank secara keseluruhan. Besar kecilnya dampak penerapan PSAK 71 terhadap penurunan KPMM/CAR sangat bergantung pada beberapa aspek, antara lain:

- Kualitas kredit

- Aktiva Tertimbang Menurut Risiko (ATMR)

- Tingkat profitabilitas

Berdasarkan hasil simulasi sederhana ini, baik dampak negatif terhadap CKPN maupun KPMM/CAR, sekali lagi hal ini mengkonfirmasi kekhawatiran selama ini akan dampak negatif yang akan ditimbulkan oleh penerapan PSAK 71.

Tabel 3. Perbandingan Persentase Perubahan Kecukupan Penyediaan Modal Minimum (KPPM) PSAK 55 dan PSAK 71

\begin{tabular}{|c|c|c|c|c|c|}
\hline Keterangan & TrisulanI & Triwulan II & Triwulan II & Triwulan IV & Rata-rata \\
\hline KPMM(PSAK 55) & $3258 \%$ & $34.56 \%$ & $34.40 \% 6$ & 33.6296 & $33.79,6$ \\
\hline KPMM(PSAK 71) & 323296 & $34.27 \% 6$ & $34.13 \%$ & $3333 \%$ & $33.51 \%$ \\
\hline 96 Naik (Turun) & $-026 \%$ & -0.2996 & $-0.27 \%$ & -02976 & $-0.28 \% 6$ \\
\hline
\end{tabular}

\section{PERSIAPAN PENERAPAN PSAK 71}

Mempertimbangkan dampak yang cukup besar khususnya terkait dengan permodalan, maka Bank-bank perlu mempersiapkan penerapan PSAK 71 dengan baik. Beberapa langkah dan
Menurut hemat penulis, bukan besar atau kecilnya dampak penurunan yang perlu diperhatikan, karena hal tersebut masih tergantung dari berbagai aspek yang telah diuraikan sebelumnya, namun persiapan apa yang harus dilakukan agar pelaksanaan penerapan PSAK 71 ini dapat berjalan baik dan lancar. Dampak memang harus diantisipasi dari sekarang, namun yang tidak kalah penting adalah menetapkan langkah persiapan, khususnya system modeling yang akan digunakan yang mengkombinasikan data historis dan looking forward. Kehandalan dalam menciptakan system modeling pada akhirnya akan menyajikan data keuangan yang akurat, dan hal inilah sebenarnya esensi dari diterapkannya PSAK 71. 


\section{TEKNIS}

- Menetapkan indikator dan batasan perpindahan antar "bucket", khususnya perpindahan dari "bucket 1" ke "bucket 2".

- Mendefinisikan dan mengidentifikasi terkait informasi penting untuk menjembatani model yang digunakan saat ini dengan model multi-years sesuai dengan yang dipersyaratkan dalam menetapkan "expected loss".

\section{OPERASIONAL}

- Ketersediaan data (data historis, data internal, data eksternal, data operasional, dll)

- Kualitas data

- Laporan keuangan (internal \& eksternal, kualitatif \& kuantitatif)

- Manajemen pelaporan (proses control, governance)

- Pelaporan berkala

- Dampak terhadap Sistem Teknologi Informasi (bank data, system terintegrasi, perhitungan secara otomatis, dll)

- Sumber Daya Manusia (pengetahuan, kompetensi, ketrampilan, dll)

\section{KESIMPULAN}

Penerapan PSAK 71 selain bermanfaat dalam menyajikan informasi relevan dan berguna bagi pengguna laporan keuangan untuk melakukan penilaian terhadap jumlah, waktu dan ketidakpastian arus kas masa depan entitas, namun memberikan dampak negatif baik terhadap peningkatan Cadangan Kerugian Penurunan Nilai (CKPN) maupun KPMM/CAR.

Berdasarkan simulasi yang dilakukan terhadap salah satu Bank Swasta Nasional Kategori BUKU 2, penerapan PSAK 71 ini memberikan dampak peningkatan CKPN sebesar rata-rata $55,68 \%$, sementara terhadap KPMM/CAR, penerapan PSAK 71 ini memberikan dampak penurunan KPMM/CAR rata-rata $0,28 \%$.

Mempertimbangkan dampak yang cukup besar khususnya terkait dengan permodalan, maka Bank-bank perlu mempersiapkan penerapan PSAK 71 dengan baik melalui langkah persiapan baik dari aspek strategic, teknis maupun operasional.

\section{DAFTAR PUSTAKA:}

Epstein, Barry J. \& Jermakowicz, Eva K. 2007. IFRS: Interpretation and Aplication of International Financial Reporting Standards, John Wiley \& Sons, Inc.

Dewan Standar Akuntansi Keuangan Ikatan Akuntan Indonesia. 2016. Exposure Draft Pernyataan Standar Akuntansi Keuangan 71 Instrumen Keuangan. IAI. 
Dewan Standar Akuntansi Keuangan Ikatan Akuntan Indonesia. 2016. Materi Public Hearing ED PSAK 71 Instrumen Keuangan.

IASB. 2014. IFRS 9 Financial Instrumen, IFRS Foundation.
Weygandt, Kimmel, \& Kieso. 2013. Financial Accounting, IFRS Edition, John Wiley \& Sons, Inc 